\title{
Motorsports Management: Opportunities, Issues and Challenges
}

\author{
Syarizal Abdul Rahim and Norailis Ab. Wahab
}

\begin{abstract}
The collaboration between FASTrack Autosports Pte. Ltd. (Singapore) and UEM Land Berhad (Malaysia) to build a RM3.5 billion Motorsports City in Johor's Iskandar region provides greater prospects for the nation and to motorsports devotees. Hence, this paper aims to focus on certain motorsports issues including its opportunities and challenges. It commences with the development of motorsports in Malaysia. Although, this paper is constrained by the paucity of academic literatures on motorsports from the management perspective however, together with the results of interview from two key people in the motorsports industry and the authors' experience with practitioners in the respective business, some issues that came to light are pointed out including organizational and human resource. On the basis of the authors' understanding of the progressively multifaceted activities of this industry, much attention needs to be focused on the opportunities of this sport and some issues are demanding immediate actions. More awareness needs to be given to motorsport events as well as increased research efforts on this industry. Significant findings from the management perspectives perhaps might influence policy making and practice inside the track.
\end{abstract}

Index Terms-Organizational, human resource, management, motorsports.

\section{INTRODUCTION}

Motorsports contribute to tourism revenue via many foreign fans who come to Malaysia and are most likely to extend their stay an to an average of six days and spend about RM7,000 during that period. For instance, Malaysian GP in 2011 generated a total economic activities of RM200 million [1]. Besides tourism, the sport also benefits other sectors such as technology transfer involving Petronas and Proton. In addition, the collaboration between FASTrack Autosports Pte. Ltd. (Singapore) and UEM Land Berhad (Malaysia) to build a RM3.5 billion Motorsports City in Johor's Iskandar region provides greater prospects for the nation and motorsports devotees particularly to experience specialties from school to the racing tracks. Although it seems that this will provide many opportunities to young Malaysians, there are some issues that need to be tackled by the government and private sectors in order to raise the level of this sport. For instance, the sport simply occupy a niche area in Malaysia instead of being an independent industry although good facilities especially tracks such as those in Batu Tiga Speedway Circuit, Johor Circuit and Sepang International

Manuscript received May 20, 2013; revised July 15, 2013.

Syarizal Abdul Rahim is with the Faculty of Business and Entrepreneurship, Universiti Malaysia Kelantan, Malaysia (e-mail:syarizal.ar@umk.edu.my).

Norailis Ab. Wahab is with the Faculty of Economics and Muamalat, Universiti Sains Islam Malaysia.
Circuit (SIC) has been recognized at the international level. Therefore, this paper aims to highlight issues regarding talents and facilities in the motorsports.

The journey of Malaysian motorsports started with the opening of Batu Tiga Speedway Circuit in 1968 and with the first Grand Prix (GP) in the same year. It was the venue for the Malaysian GP until 1982, during which the starting field consisted of vehicles from the Formula Atlantic and Formula Pacific or Formula 2. The circuit hosted rounds of the Superbike World Championship in 1990 and 1991 while from 1991 to 1997 it hosted the Malaysian Motorcycle GP. The GP was later moved to the Johor Circuit (formerly known as Pasir Gudang Circuit).

Pasir Gudang Circuit was built in 1986 and it is the first international class motor racing circuit outside of the Klang Valley. It initially catered for the growing local enthusiasts but soon gained recognition not only regionally, but also internationally. In 1990, just four years after it was built, the circuit was upgraded to the strict Federation Internationale de Motocyclisme (FIM) World GP requirements. In 1998, it hosted the World Motorcycle GP Championship. Ever since then, it has been hosting regular local and regional events. Soon after, the state-of-the-art circuit, Sepang International Circuit (SIC) was officially opened in 1999. Within the same year, the F1 GP fraternity's presence in Asia was limited to Japan but the sports spread to Malaysia. In this place called 'Home of Motorsports' lies the aspiration of making Malaysia the hub for motor racing activities in the region and a catalyst to spark a new beginning for Malaysia's motorsports industry.

\section{Motorsports In MANAGEMENT AND MARKETING}

Management, the main focus of this article, is just one of the required variables in the motorsports area. Chadwick [2] [3] had identified management challenges in organizational and human resource such as issues on culture, performance, networks and the roles of different sectors in that particular niche. Moreover, he suggested that there is a growing research interest in sports that sets out to examine more issues in other areas for the basis of decision-making in pertinent occasion related to these particular events.

It has been shown that most literature references on motorsports focused on the marketing aspects [4]-[6]. Olson [7] also reported the same trend in various sports events. He suggested that sponsorship managers working in cultural contexts can be fairly confident that the research findings in sports contexts are also relevant to their own situation. In addition, Cornwell et al. [8] pointed out the roles of corporate sponsorship during motorsports events as perceived by managers. It was the first time in the literature that was 
measured objectively. As in their findings, they pointed out the roles of corporate sponsorship during motorsports events and their findings contributes to the growing argument that sponsorships must be supported by collateral investments in advertising and promotion. Besides, Pruitt et al. [9] revealed that the difference between motorsports and other ball-and stick type sports is that enthusiasts see a direct connection to the viability of the sport based on sponsors. For example, in superbikes tournaments, Honda is known for their ability to innovate prototypes with colours, better engines, more bikes, more testing and putting more into their program [10]. Honda applies kaizen (continuous improvement) in all areas and this makes it the one of the most profitable automaker. This also influences the team performance as well as fans loyalty. From the marketing scholars perspective, the ability to achieve future prosperity for motorsports depends almost entirely upon its solid marketing which can guarantee continuous financial returns to its many corporate sponsors. On the other hand, Lawson [11] shared his experience during a break from an accident in his career by saying "the vast numbers of training and experiences in races influences your body and mind to do only things that are related to it". It was like a programmed behaviour which also affect his reaction towards close individual around him.

\section{Methodology}

The researchers' intention is to develop a more appropriate basis for judging the plausibility of qualitative field studies in motorsports. Thus, the authors emphasized in particular the distinctive role of theory in qualitative research as relating to expression of a subjective reality. In considering this subjectivity, the commentary presented reflects the authors' knowledge, skills and experiences in conjunction with the results of interview with two key individuals in the field of motorsports business in Malaysia.

\section{FINDINGS AND DISCUSSION}

It seemed that motorsports is only a niche in Malaysia's sports environment; a complex area that has multifaceted issues as well as prospects. From the interviews, there are two significant findings that shall be emphasized: talents and facilities. The following challenges and opportunities dealing with talents and facilities will be discussed in detail.

\section{A. Challenges}

It is important for riders to familiarize themselves with tracks and to set up bikes according to the track conditions. To date, it has been difficult to expand pool of talents in motorsports due to full booking of tracks. Although there are choices of two standard racing tracks, only SIC provides the best venue that meets Federation Internationale deI'Automobile (FIA) requirement. This is coupled with the fact that it is located in the heart of Malaysia thus making it more accessible. Additionally, SIC is considered as an expensive track rental - RM50,000 (equivalent to USD $\$ 15,000$ ) for a full day which consequently results in lots of effort in looking for funds or sponsorship. However, there are chances of gradual track day that is open to the public. This occasion involves different specifications of bikes ride by professional and novice riders as well as coping with their different attitudes such as slow versus fast riders which can cause traffic during the practice on the same track.

From the organizer's part, there are limited numbers of observation points to see the riders' performance at different turns during practices. This constraint affects the learning process during the practices which might prevent the organizers from noting the area or skills of participated riders that should be improved.

Since the talents are the vital aspect in motorsports, there are needs for proper coaching to enhance their riding skills. Referring to the limited pools of talents from formal learning, therefore the best way to look for the talents is to find them among rempits, individuals who participate in illegal street races. The motorsports already picked up public interest since Zulfahmi Khairuddin, a formal rempit made his debut in $125 \mathrm{cc}$ championship in the 2009 Malaysian Grand Prix. Unavailability of formal superbike schools and budgetary constraints in inviting practitioners as well as professional riders has limited the potential of young talents in this sport.

Usually, local riders start their career in motorsports using underbone small light motorcycles called kapcai. The engine size of a kapcai is generally ranging between $50 \mathrm{cc}$ and up to $135 \mathrm{cc}$. These circumstances confined their participation in lower rank of competitions at the national or Asian levels which involved lower capacity of engines. On top of that, annual race events involved more kapcais instead of other types of bikes to attract more participation from public e.g. Kapcai Endurance organizes by Motorsport Association of Malaysia (MAM) and Malaysian Cup Prix Championship by Automobile Association of Malaysia (AAM).

In some cases, team owner only wanted to observe potential riders' abilities instead of the bikes they owned. They would be assessed through injuries, skills to handle the ride, speed control, how they take turn into the corner and time taken to complete a course. Referring to the current local scenarios, there is no rental services for proper attires and standard racing bikes provided for the riders to be tested on race tracks.

Another issue is related to sponsorship. At one time, sponsors gave their fund to a specific workshop that played a role as the team owner. Usually, the sponsorship should be able to cover the cost of bikes and other additional expenses engaged in a series of races. If a team owner received an amount lower that he proposed to the sponsor, he would only be able to provide lower quality bikes which might affect the performance of riders across races. Regardless the sizes of fund given, the sponsors wanted to see their riders' best positions as a return.

Motorsports is a dangerous sport; to attract more young talents and support their participation on race tracks required a lot of money to be invested in engine modification, specialty tools, event fees, track entrance, proper attire, fuel as well as food and lodging. However, this investment could be varies by facilities and expected turnouts, either win or lose during competitions. Furthermore, a successful career in motorsports is a function of successes in races and availability of long term sponsorship.

In spite of everything, career path for the riders are not clear from the beginning until they plan to retire. Dilemma of being full time riders or only as a hobby is an issue for those 
who are enthusiast with this sport. Years of hard work, focus and effort could be a waste if they did not plan well for the next phase in their life. In fact, by choosing to be in the motorsport seriously as in their early age, they missed out opportunities in getting formal education as well as being a degree holder as their other friends.

\section{B. Opportunities}

The facilities in SIC which is the best in the country provides big tracks, comply with world class condition and weather that is good for tires testing as well as good support facilities for training including motocross tracks. More so, its location is close to Malaysia's main entrance - Kuala Lumpur International Airport (KLIA). The Johor Circuit can be utilize at lower costs and also offers high availability of usage due to fewer events organized at national level. Although most users or racers are from Singapore, the possibilities for local fresh talents are not being sideline by the organizers.

Malaysia is putting more young talents in the international events although with less accommodations as compared to Japan and European countries into this sport such as Zulfahmi Khairuddin (Moto3 class, MotoGP), Hafizh Syahrin Abdullah (full season race in Spain), Hafiq Azmi (represents Redbull KTM), Zaqhwan Zaidi and Azlan Shah Kamaruzzaman, (600cc class SuperSports, Asia Road Racing Championship). These riders have different riding style for different categories and competitions which represent different sponsors.

Motorsport already has picked up more Malaysian interest due to interest participation of rempit on tracks. This kind of interest promoted them to be icons in the particular sport instead of foreign racers. This can be seen as their fans did not hesitate to wear t-shirts and hats with their name on it.

In addition, more parents are actively played their part in encouraging their children to take part in competition as early as eight years old. They are responsible to provide full attire and pocket bike for the youngsters to be trained on tracks. On top of that, this sport required parents' continuous commitment in term of time and money. On the other hand, they should take the lead to request workshops or team owners to teach and expose their children to motorsports. For instance, Hafizh Syahrin began his career with help from his father, a mechanic and a former local racer. As for him, being around the globe at the same time as has to maintain credibility requires high motivation especially from the closest family member. His father accompanied him in all races promised Hafizh a great focus on the career instead of being playful due to his young age.

Most of former racers decided to be in the motorbikes-related businesses after their time; without proper formal education and business background. However, they are able to go beyond technical and engineering areas such as marketing, logistics, hospitality and sales although have to relied on their experiences, networks and supporters to move ahead. Most of the cases, they became riders' team owner for their apprentices or run workshop at the same time as look for the best talents among their clients.

In order to sustain motorsports and to add new names to the list of varies competitions at the international level; there is a need for knowledge transfer from the expertise through structured programs by independent organizers in a calendar year throughout the country. Active participation in races will open more opportunities in improving skills on tracks performance of young racing talents in motorsports.

\section{CONCLUSION}

The limitation of study is that this paper only focused on the facilities, not only at the organizational level and talents individual and team that are currently available in Malaysia. In summary, these authors made a first step in understanding the current situation of motorsports management and in building formulas for further development. In order to produce good reputation in motorsports, it is very important to stimulate strong interest among parties. Malaysia Youth and Sports Ministry programs focuses on sports in general due to limited allocation. Most of the roles are played by independent organization such as Motorsports Association of Malaysia (MAM), Automobile Association of Malaysia (AAM) and SIC. They are the organizers of most programmes and events related to motorsports as well as to discover young talents by collaborating with other talent finder such as businesses in the same niche. Although the focus of this paper is more on management viewpoint rather than technical, there are rooms for future research to be explored in this area.

\section{REFERENCES}

[1] News Straits Times. 2012. F1 Race Generates Tourism Revenue. [Online]. Available:

http://www.nst.com.my/nation/general/f1-race-generates-tourism-reve nue-1.64963.

[2] C. Simon, "From outside lane into inside track: sport management research in the twenty-first century," Management Decision, vol. 47, no. 1, pp. 191-203, 2009

[3] C. Simon, "Sports steps up to take the inside track," Sports, Business and Management: An International Journal, vol. 1, no. 1, pp. 5-11, 2011.

[4] C. T. Bettina, S. W. Pruitt, and N. R. Van, "An exploratory analysis of the value of winning in motorsports: Sponsorship-linked marketing," Journal of Advertising Research, pp. 17-31, Jan-Feb, 2001.

[5] H. Bill, "Measuring the effects of sponsorships," Journal of Advertising Research, pp. 59-65, Jan-Feb. 2001.

[6] L. Thierry and G. Q. Pascale, "Attitudinal effects of combined sponsorship and sponsor's prominence on basketball in Europe," Journal of Advertising Research, pp. 48-58, Jan-Feb. 2001.

[7] L. O. Erik, "Does sponsorship work in the same way in different sponsorship contexts?" European Journal of Marketing, vol. 44, no. 1-2, pp. 180-199, 2010.

[8] C. T. Bettina, D. P. Roy, and E. A. Steinard II, "Exploring managers' perceptions of the impact of sponsorship on brand equity," Journal of Advertising, vol. XXX, no. 2, pp. 41-51, 2001.

[9] W. P. Stephen, C. T. Bettina, and J. M. Clark, "The NASCAR phenomenon: auto racing sponsorships and shareholder wealth," Journal of Advertising Research, pp. 281-296, September, 2004.

[10] A. Taylor III, "Honda goes its own way," Fortune (Switzerland), vol. 146, no. 2, pp. 56, 2002.

[11] L. Ron. (2004). From the saddle: programmed behavior. pp. 8. [Online] Available: http:www.dirtbikemagazine.com

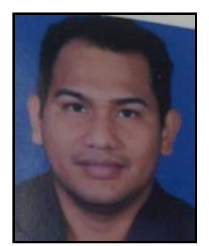

Syarizal Abdul Rahim is a lecturer in Universiti Malaysia Kelantan, Malaysia. He was born in Mentakab, Pahang in June, 1976. He obtained his first degree in Accounting from Universiti Teknologi MARA (UiTM) in 1999. After ten years, he completed master in Business Administration from Universiti Utara Malaysia (UUM). From 2002 to 2005, he was employed by Royal Bank of Scotland in Aberdeen. Then, he decided to change his direction by worked for Standard Chartered Bank in Singapore for four years. Before he joined the academics, he attached with Bank Muamalat Malaysia Berhad until early this year. He is a member Automobile 
Association of Malaysia (AAM) due to high involvement in motorsports. His research interests are business and management particularly in motorsports.

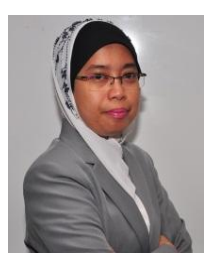

Norailis Ab. Wahab is a senior lecturer in the Faculty of Economics and Muamalat, Universiti Sains Islam Malaysia. She is a member of Malaysian Muamalat Association (MMA) and The Malaysian Consumer and Family Economics Association (MACFEA). She was born on September 4, 1978 in Negeri Sembilan, Malaysia. She attained her first degree in Industrial Economics in 2000 and Master in Science (Productivity and Quality Enhancement) in the following year from Universiti Kebangsaan Malaysia.

In the middle of 2009 , she had been awarded Ph.D. from the University of Stirling, Scotland. She joined SME Corporation Malaysia for three months in 2012 through USIM Academic Staff Attachment Program to gain industrial experiences and strengthen the networking with practitioners in small and medium enterprises (SMEs). This year, she has published two case studies on umrah management and organizational issues in "Integrated Muamalat Case Study" published by the PENERBIT Universiti Sains Islam Malaysia. She is actively involves in research on benchmarking, supply chain and umrah management. 